\title{
CORRIGENDA
}

\section{Nuclear localization of the adenovirus E4orf4 protein is mediated through an arginine-rich motif and correlates with cell death}

\author{
Marie-Joëlle Miron, Imed-Eddine Gallouzi, Josée N Lavoie and Philip E Branton
}

Oncogene (2005) 24, 4162. doi:10.1038/sj.onc.1208769

Correction to: Oncogene (2004) 23, 7458-7468.

doi: $10.1038 /$ sj.onc. 1207919

Published online 30 August 2004
Since publication of the above manuscript, the authors have identified an error in Figure 3. The correct version of the figure is given below. a

GFP-HA-E4orf4

GFP-E4(62-95)

GFP-E4(62-79)

GFP-E4(66-75)

GFP-TatARM

GFP-RevARM

b GFP-HA-E4orf4

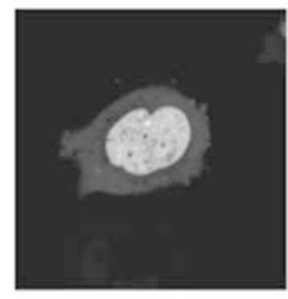

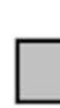

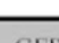

GFP

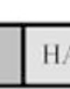

1A

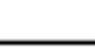

E4ori

E4ARM
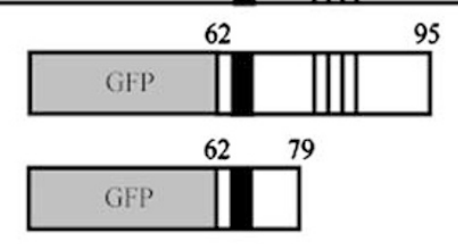

6675
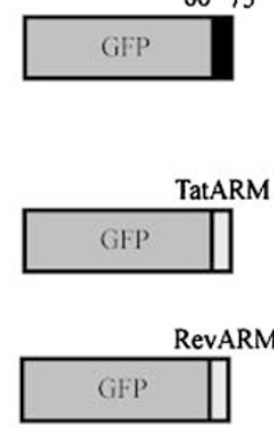

GFP-EA(62-95)

GFP-E4(62-79)

GFP-E4(66-75)

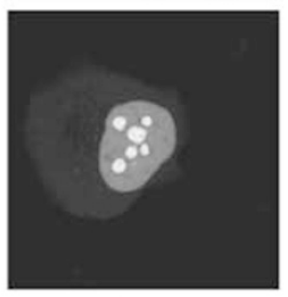

GFP-TatARM
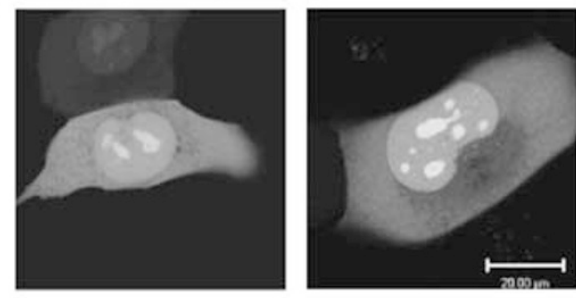

GFP-RevARM

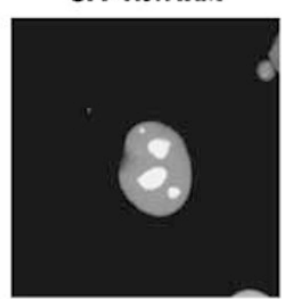

